\title{
PENGGUNAAN MODEL DISCOVERY LEARNING UNTUK MENINGKATKAN HASIL BELAJAR KELAS VIIIJ SMPN 5 KOTA BENGKULU
}

\author{
Tiyas Utami Verdianingsih ${ }^{{ }^{*}}$, Sri Irawati ${ }^{1}$, Dewi Jumiarni ${ }^{1}$ \\ ${ }^{1}$ Program Studi Pendidikan Biologi, Fakultas Keguruan dan Ilmu Pendidikan, Universitas Bengkulu \\ Email: tiyasutamivn@gmail.com
}

\begin{abstract}
Abstrak
Penelitian ini bertujuan untuk mendeskripsikan hasil belajar peserta didik menggunakan model Discovery Learning di Kelas VIII $\mathrm{j}_{\mathrm{j}}$ SMPN 5 Kota Bengkulu. Jenis penelitian ini adalah penelitian tindakan kelas dengan metode deskriptif. Penelitian ini terdiri dari dua siklus, masing-masing siklus terdiri dari 4 tahap yaitu : tahap perencanaan, pelaksanaan, pengamatan dan refleksi. Subjek penelitian ini adalah guru dan seluruh peserta didik kelas VIII dengan sampel siswa kelas VIII $\mathrm{S}_{\mathrm{S}} \mathrm{MPN} 5$ Kota Bengkulu. Variabel penelitian ini adalah model Discovery Learning dan hasil belajar ranah kognitif dan psikomotor. Teknik pengumpulan data dalam penelitian ini yaitu observasi dan tes. Hasil analisis data persentase ketuntasan hasil belajar ranah kognitif pada siklus I yaitu 63,3\% yang termasuk kedalam kategori belum tuntas dan pada siklus II persentase ketuntasan hasil belajar peserta didik dalam ranah kognitif mengalami peningkatan menjadi $80 \%$ dan termasuk dalam kategori tuntas. Selanjutnya hasil analisis data hasil belajar peserta didik ranah psikomotor siklus I diperoleh skor rata-rata yaitu 14,03 (baik) dan pada siklus II skor hasil belajar peserta didik ranah psikomotor menjadi 17 (baik). Dari hasil penelitian dapat disimpulkan bahwa model pembelajaran Discovery Learning dapat meningkatkan hasil belajar peserta didik di Kelas VIII $\mathrm{j}$ SMPN 5 Kota Bengkulu.
\end{abstract}

Kata kunci : Model Discovery Learning, Sistem Pernapasan Manusia, Hasil Belajar

\begin{abstract}
This study aimed to describe learning outcomes students by applying Discovery Learning model in class $\mathrm{VIII}_{\mathrm{j}}$ SMPN 5 Bengkulu City. The type of this research was Classroom Action Research with descriptive method. This research consisted of two cycles, each cycle consist four phases: planning, implementation, observation and reflection. The subject of this research were teacher and all students of class VIII with sample was class VIII SMPN 5 Bengkulu City. The variables of this research were Discovery Learning model and learning outcomes students of cognitive and psychomotor aspects. Technique of collecting data in this research were observation and test. The results of data analysis, the percentage of learning outcomes students of cognitive aspect in the first cycle was 63,3\% (not complete) and in second cycle the percentage of learning outcomes students of cognitive aspect had increased to $80 \%$ (complete). Furthermore, the results of data analysis of the learning outcomes students of psychomotor aspect in first cycle was 14,03 (good) and in the second cycle the score of psychomotor learning outcomes increased to 17 (good). The results of this research can be concluded that the model Discovery Learning can improved learning outcomes of class VIII SMPN 5 Bengkulu City.

Key words : Discovery Learning Model, Human Respiratory System, Learning Outcomes
\end{abstract}

\section{PENDAHULUAN}

Undang-Undang Nomor 20 tahun

mewujudkan suatu proses pembelajaran

2003 mendefinisikan pendidikan adalah

usaha sadar dan terencana untuk

agar peserta didik secara aktif

mengembangkan potensi dirinya untuk 
memiliki kekuatan spiritual keagamaan, pengendalian diri, kepribadian, kecerdasan, serta keterampilan yang diperlukan dirinya, masyarakat, bangsa dan negara. Fungsi pendidikan nasional dalam Undang-Undang ini adalah mengembangkan kemampuan dan membentuk watak serta peradaban bangsa yang bermartabat dalam rangka mencerdaskan kehidupan bangsa.

Dalam suatu pendidikan, terdapat salah satu aspek yang penting yaitu kurikulum, dengan adanya kurikulum maka tujuan pendidikan tersebut dapat tercapai. Menurut Machali (2014) kurikulum sebagai produk kebijakan bersifat dinamis, kontekstual, dan relatif, karena kurikulum sangat dibutuhkan yang didasarkan pada konteks zamannya sehingga menyesuaikan dengan perkembangan zaman. Saat ini kurikulum yang diterapkan dalam dunia pendidikan Indonesia adalah Kurikulum 2013. Proses pelaksanaan pembelajaran Kurikulum 2013 pada semua jenjang pendidikan menggunakan pendekatan ilmiah (Scientific Approach) dengan mencakup tiga ranah, yaitu sikap, psikomotor, dan pengetahuan. Hilda (2015) menyatakan bahwa pembelajaran dengan pendekatan saintifik ini menekankan pada pemberian pengalaman secara langsung.

Pada Permendikbud Nomor 58 tahun 2014 tentang Kurikulum 2013 Sekolah Menengah Pertama/Madrasah Tsanawiyah dijelaskan bahwa mata pelajaran IImu Pengetahuan Alam (IPA) berkaitan dengan cara mencari tahu tentang alam secara sistematis. Pengetahuan IPA tersebut dapat diperoleh melalui suatu proses ilmiah yang memberikan kesempatan kepada peserta didik untuk memperoleh pengalaman langsung. Proses ilmiah ini dapat dilakukan dengan menerapkan suatu model pembelajaran, salah satu yang dapat digunakan adalah model Discovery Learning.

Karakteristik utama model pembelajaran Discovery Learning menurut Hosnan (2014) adalah: 1) mengeksplorasi dan memecahkan masalah untuk menciptakan, menggabungkan dan menggeneralisasi pengetahuan; (2) berpusat pada siswa; dan (3) kegiatan yang menggabungkan pengetahuan baru dengan pengetahuan yang sudah ada. Pembelajaran dengan model penemuan (Discovery Learning) merupakan suatu komponen penting dalam pendekatan konstruktivis. Dalam pembelajaran penemuan, guru hanya memberikan dorongan, sedangkan peserta didik terlibat aktif dengan konsep-konsep, prinsip-prinsip yang memungkinkan dapat mereka temukan sendiri. Oleh karena itu, pengetahuan dan keterampilan yang dimiliki peserta didik bukan hasil dari mengingat fakta-fakta, tetapi berdasarkan temuan mereka sendiri (Suprihatiningrum, 2016).

Salah satu sekolah di Kota Bengkulu yang telah menerapkan Kurikulum 2013 adalah SMPN 5 Kota Bengkulu. Berdasarkan hasil wawancara dengan guru IPA dan observasi awal peneliti diperoleh informasi bahwa model Discovery Learning telah dilaksanakan oleh guru tersebut, namun belum optimal. Hal ini dikarenakan dalam pembelajaran guru kurang melibatkan peserta didik, sehingga pembelajaran banyak berpusat pada guru yang menyebabkan siswa kurang aktif dalam memecahkan masalah yang berkaitan dengan materi yang disampaikan.

Oleh karena itu, hasil belajar peserta didik masih tergolong rendah Ini terlihat dari hasil ujian IPA yang dilaksanakan pada semester ganjil tahun 2018 hanya 3 dari 30 
peserta didik yang mencapai nilai diatas KKM yang telah ditetapkan yaitu $\geq 78$. Artinya hanya $10 \%$ peserta didik yang tuntas, sedangkan ketuntasan klasikal yang telah ditetapkan di SMPN 5 Kota Bengkulu pada mata pelajaran IPA kelas VIII yaitu $\geq$ $80 \%$.

Dari permasalahan tersebut, peneliti bekerja sama dengan guru IPA kelas VIIIj SMPN 5 Kota Bengkulu untuk menerapkan model pembelajaran Discovery Learning dengan melaksanakan langkah-langkah pembelajaran sesuai sintaksnya. Hal ini penting dalam menentukan perbaikan pembelajaran IPA biologi di Kelas VIII SMPN 5 Kota Bengkulu, sehingga hasil belajar peserta didik dapat meningkat seiring meningkatnya aktivitas proses pembelajaran.

\section{METODE}

Jenis penelitian ini adalah penelitian tindakan kelas dengan metode deskriptif. Penelitian ini dilakukan dalam 2 siklus yang terdiri dari 4 tahapan proses pembelajaran yaitu perencanaan, tindakan, pengamatan dan refleksi. Materi siklus pertama mengenai organ pernapasan dan mekanisme pernapasan manusia, dan siklus kedua mengenai frekuensi pernapasan manusia. Subjek penelitian ini adalah guru peneliti dan seluruh peserta didik kelas VIII dan yang menjadi sampel kelas VIIIj SMPN 5 Kota Bengkulu tahun ajaran 2018/2019 berjumlah 30 orang yang terdiri dari 22 peserta didik laki-laki dan 8 peserta didik perempuan.

Teknik pengumpulan data yang digunakan dalam penelitian ini adalah teknik observasi dan tes, dengan instrumen penelitiannya yaitu lembar observasi dan lembar tes. Lembar observasi digunakan untuk menilai aktivitas guru dan aktivitas peserta didik serta psikomotorik peserta didik selama proses pembelajaran dengan model Discovery Learning. Sedangkan lembar tes digunakan untuk mengukur hasil belajar peserta didik ranah psikomkotor yang terdiri dari soal-soal pilihan ganda berjumlah 10 soal dan diberikan saat akhir pembelajaran. Soal tes tersebut dirumuskan berdasarkan 3 aspek kognitif, yaitu C1 (pengetahuan), C2 (pemahaman), dan C3 (Penerapan). Tes objektif/ pilihan ganda ini memiliki objektivitas yang tinggi. Sesuai dengan pernyataan Kadir (2015) bahwa tes pilihan ganda itu merupakan tes objektif yang memiliki ciri utama yaitu jawaban yang jelas dan pasti, sehingga hasilnya dapat dinilai secara objektif. Artinya, setelah peserta didik selesai mengerjakan soal dalam bentuk pilihan ganda, maka akan memperoleh nilai yang sama walaupun diperiksa oleh lebih dari satu pemeriksa.

Kriteria Ketuntasan Minimal yang ditetapkan untuk mata pelajaran IPA kelas VIII pada masing-masing peserta didik adalah $\geq 78$. Kemudian untuk persentase ketuntasan klasikal dapat dihitung dengan menggunakan rumus:

$$
\mathrm{P}=\frac{\sum X}{N} \mathrm{X} 100 \%
$$

(Sudijono, 2015).

Keterangan:

$\mathrm{P}=$ Persentase ketuntasan hasil belajar peserta didik

$\Sigma \mathrm{x}=$ jumlah peserta didik yang berada diatas KKM

$\mathrm{N}$ = Jumlah seluruh peserta didik

Ketuntasan klasikal pada mata pelajaran IPA Kelas VIII SMPN 5 Kota Bengkulu yang ditetapkan adalah $\geq 80 \%$. Jadi dapat dikatakan tuntas apabila $\geq 80 \%$ dari jumlah keseluruhan peserta didik mendapatkan nilai $\geq 78$. 
Data hasil observasi yang diperoleh tersebut digunakan untuk merefleksikan hasil belajar peserta didik ranah psikomotor, yang akan di rata-rata dengan menghitung:

Rata-rata skor $=\frac{\text { jumlah skor }}{\text { jumlah aspek pengamatan }}$

(Sudijono, 2015).

Penentuan kategori rerata hasil pengamatan dilakukan dengan menentukan kisaran skor kategori kurang (K), cukup (C), dan baik (B). Untuk kisaran rerata dapat digunakan dengan menghitung:

\section{Kisaran skor untuk setiap kategori= skor tertinggi-skor terendah jumlah kategori penilaian}

(Arikunto, 2009).

\section{Keterangan:}

Skor tertinggi $=$ jumlah butir pengamatan $\mathrm{x}$ skor maksimum setiap butir

Skor terendah $=$ jumlah butir pengamatan $\mathrm{x}$ skor minimum setiap butir

Lembar observasi aktivitas mengajar guru dan aktivitas belajar peserta didik berjumlah 16 butir pengamatan, skor tertinggi tiap butir 3 dan skor terendah tiap butir 1, maka kategori penilaian untuk lembar observasi aktivitas guru dan aktivitas peserta didik dapat dilihat pada Tabel 1.

Tabel 1. Kategori penilaian aktivitas guru dan aktivitas peserta didik

\begin{tabular}{cc}
\hline $\begin{array}{c}\text { Rentang } \\
\text { skor }\end{array}$ & Kategori Penilaian \\
\hline $16-26$ & Kurang \\
$27-37$ & Cukup \\
$38-48$ & Baik \\
\hline
\end{tabular}

Lembar observasi psikomotorik peserta didik berjumlah 6 butir pengamatan dengan skor tertinggi tiap butir 3 dan skor terendah tiap butir 1. Oleh karena itu, kategori penilaian untuk lembar observasi psikomotoris peserta didik dapat dilihat pada Tabel 2.

Tabel 2. Kategori penilaian observasi psikomotorik peserta didik

\begin{tabular}{cc}
\hline Rentang skor & Kategori Penilaian \\
\hline $6-9$ & Kurang \\
$10-13$ & Cukup \\
$14-18$ & Baik \\
\hline
\end{tabular}

\section{HASIL DAN PEMBAHASAN}

Berdasarkan hasil penelitian yang telah dilakukan, diperoleh skor rerata aktivitas guru dan peserta didik pada siklus I ke siklus II yang dapat dilihat pada Gambar 1 dan Gambar 2 berikut.

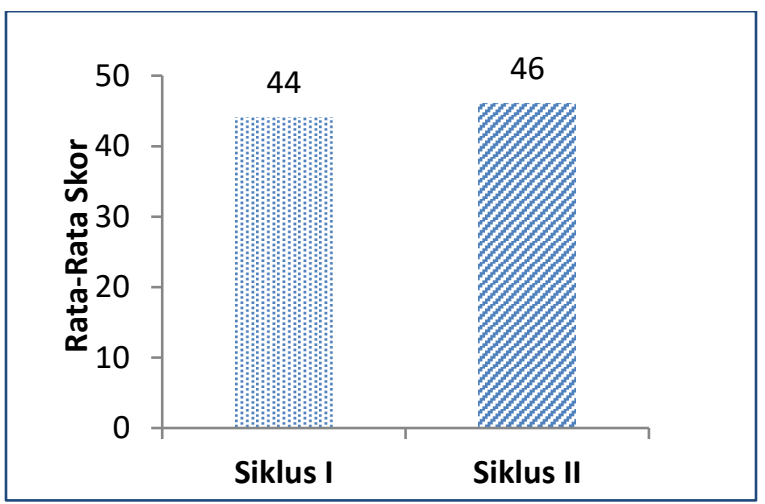

Gambar 1. Grafik rata-rata skor aktivitas guru pada siklus I dan siklus I

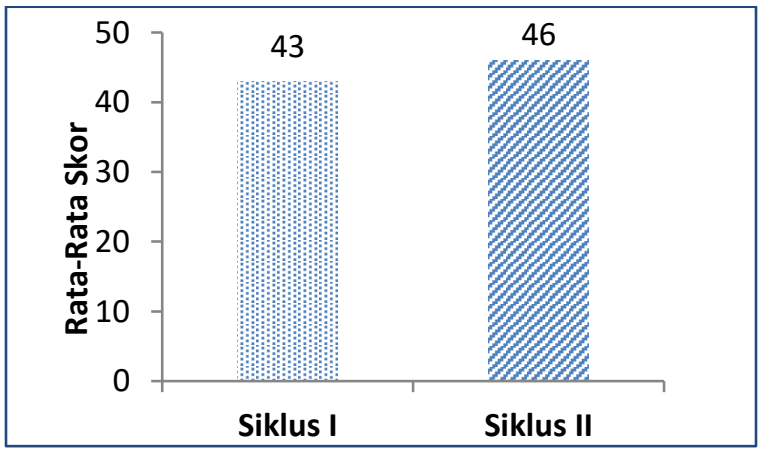

Gambar 2. Grafik rata-rata skor aktivitas peserta didik pada siklus I dan siklus II 
Berdasarkan gambar 1 dan gambar 2, dapat disimpulkan bahwa rata-rata skor aktivitas peserta didik dan guru mengalami peningkatan. Selaras dengan penelitian yang dilakukan oleh Amalia, dkk (2017) bahwa pembelajaran dengan menggunakan model Discovery Learning terbukti efektif dalam meningkatkan keterampilan berpikir luwes peserta didik. Dalam pembelajaran, aktivitas peserta didik selama mengikuti proses pembelajaran diperhatikan. Semakin peserta didik aktif, pembelajaran akan semakin efektif.

Kemudian, hasil belajar peserta didik ranah kognitif pada siklus I dan siklus II dapat dilihat pada Gambar 3.

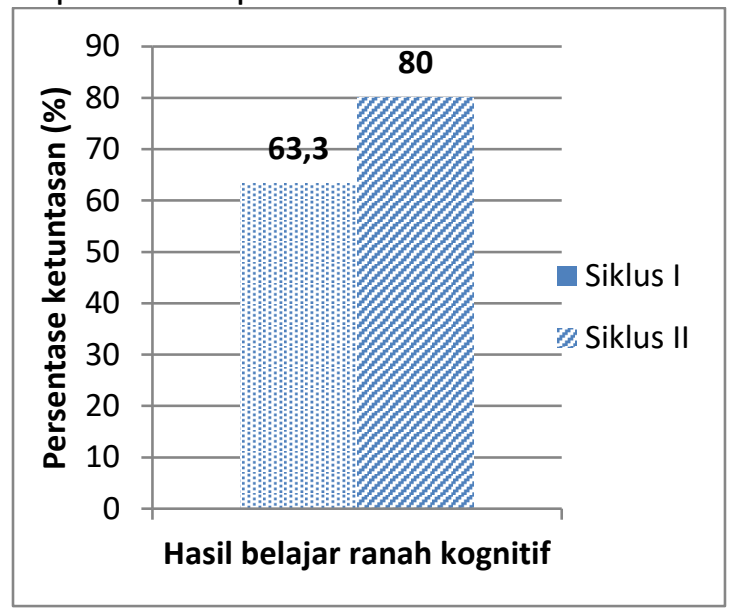

Gambar 3. Persentase Ketuntasan Klasikal Hasil Belajar Peserta Didik Ranah Kognitif Siklus I dan Siklus II

Berdasarkan gambar 3. tersebut, diketahui bahwa persentase ketuntasan klasikal peserta didik meningkat dari siklus I sebesar 63,3\% menjadi $80 \%$ di siklus II. Dari data tersebut, terjadi peningkatan hasil belajar kognitif dari siklus I ke siklus II sebesar $16,7 \%$.

Kemudian hasil observasi psikomotorik peserta didik pada siklus I dan siklus II dapat dilihat pada Gambar 4:

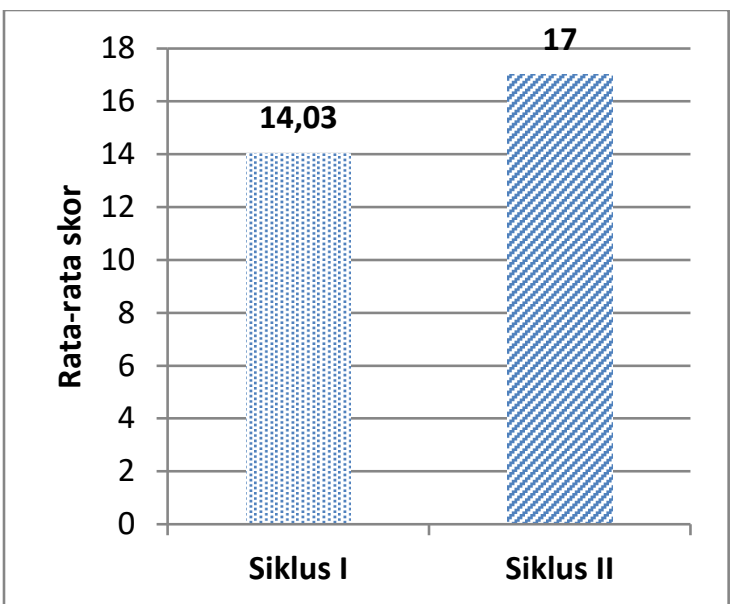

Gambar 4. Rata-Rata Skor Observasi Psikomotoris Peserta Didik pada Siklus I dan Siklus II

Berdasarkan data hasil penelitian diatas, diketahui bahwa hasil belajar yang telah diperoleh mengalami peningkatan, baik dalam ranah kognitif maupun psikomotor. Peningkatan disebabkan oleh meningkatnya aktivitas mengajar guru dan aktivitas belajar peserta didik dengan adanya penerapan model Discovery Learning yang terdiri dari 6 tahap pelaksanaan sebagai berikut:

\section{1) Stimulation (Pemberian rangsangan)}

Pada tahap ini, guru memberikan pertanyaan penyelidikan kepada peserta didik dan peserta didik mendengarkan pertanyaan penyelidikan yang diberikan guru. Pertanyaan-pertanyaan yang diberikan oleh guru pada tahap ini berdasarkan kejadian yang sering dirasakan oleh peserta didik di dalam kehidupan sehari-hari mengenai pernapasan manusia. $\mathrm{Hal}$ ini sesuai dengan pernyataan Widiadnyana, dkk (2014), bahwa pada tahap stimulation adalah dengan memberikan pertanyaan-pertanyaan yang relevan dengan kehidupan sehari-hari, yang merangsang peserta didik untuk berfikir serta dapat mendorong eksplorasi. Oleh karena itu, peserta didik diajak untuk peka terhadap berbagai kejadian yang mereka 
alami secara langsung dalam kehidupan sehari-hari.

2) Problem statement (Identifikasi masalah)

Pada tahap ini, guru mengarahkan peserta didik untuk mengemukakan pendapatnya tentang pertanyaan yang diberikan, kemudian peserta didik mengemukakan pendapatnya. Jadi disini peserta didik dituntut untuk dapat mengemukakan pendapatnya tentang pertanyaan yang diberikan oleh guru. Hal ini sejalan dengan pernyataan Sari (2018) bahwa dalam proses pembelajaran perlu dilakukan kegiatan yang dapat menuntut respon peserta didik terhadap pertanyaan yang disampaikan guru. Dengan demikian peserta didik dapat memperoleh pengetahuan dan meningkatkan kemampuan berfikir serta dapat meningkatkan partisipasi peserta didik dalam kegiatan pembelajaran.

3) Data collection (pengumpulan data) Pada tahap ini, guru menginstruksikan peserta didik dalam kelompoknya untuk membaca LKPD kemudian menjelaskan langkah kerjanya, dan guru membimbing setiap kelompok dalam mengumpulkan data percobaan materi Sistem Pernapasan. Sedangkan peserta didik mendengarkan dan memahami penjelasan mengenai langkah kerja dari guru dan peserta didik mengumpulkan data hasil pengamatan materi Sistem Pernapasan. Jadi dengan kegiatan pengumpulan data melalui percobaan yang dilakukan peserta didik membuat mereka lebih terlibat aktif dalam proses pembelajaran. Hal ini sejalan dengan pendapat Sani (2014), bahwa dengan belajar menggunakan pendekatan ilmiah akan melibatkan peserta didik dalam melakukan aktivitas menyelidiki suatu kejadian untuk menjawab pertanyaan.

4) Data processing (pengolahan data)

Pada tahap ini guru membimbing setiap kelompok dalam mengolah data hasil percobaan yang diperoleh untuk menjawab pertanyaan-pertanyaan di Lembar Kerja Peserta Didik (LKPD). Sedangkan peserta didik dalam kelompoknya menjawab pertanyaan di Lembar Kerja Peserta Didik (LKPD). Dari hasil kegiatan pada tahap ini, peserta didik diharapkan mendapat pengetahuan baru dari pemecahan masalah dengan pembuktian yang logis. Hal tersebut sesuai dengan Permendikbud (2014) bahwa tahap pengolahan data ini berfungsi untuk mendapatkan generalisasi dari kasus yang dipecahkan

5) Verification (pembuktian)

Pada tahap ini guru membimbing setiap kelompok dalam melakukan verifikasi dan peserta didik dalam kelompoknya berdiskusi dalam mlakukan pembuktian. Kegiatan ini sejalan dengan Permendikbud (2014), bahwa dari hasil pengolahan data yang kemudian ditafsirkan dapat memberikan harapan agar peserta didik mendapatkan pengetahuan yang baru dari pemecahan masalah melalui pembuktian yang logis. Jadi setelah dilakukannya percobaan, harus dibuktikan dahulu dengan membandingkannya dengan sumber yang relevan,agar konsep yang ditemukan dapat dipahami.

6) Generalization (menarik kesimpulan)

Pada tahap ini, guru membimbing satu kelompok peserta didik untuk membuat kesimpulan hasil percobaan yang dilakukan. Merumuskan kesimpulan disini merupakan sesuatu yang harus dibuat oleh peserta didik agar dapat menemukan 
jawaban setelah melalui proses berpikir dalam mencari data. Selain itu, kesimpulan akan membawa peserta didik pada suatu bentuk pengetahuan yang akurat sehingga memberikan penjelasan dan pemahaman konsep bagi peserta didik. Hal ini sejalan dengan pendapat Widiadnyana dkk (2014), bahwa tahap menarik kesimpulan dapat melahirkan sikap kemauan untuk mengubah pandangan, karena pada tahap ini ditetapkan suatu konsep tertentu yang merupakan hasil dari proses pembelajaran. Pada penelitian Putri dkk (2017) dijelaskan bahwa Model pembelajaran Discovery Learning berdampak terhadap hasil belajar siswa dan aktivitas siswa. Aktivitas siswa yang meningkat akan berpengaruh terhadap hasil belajar siswa. Hal ini terlihat dari peningkatan perkembangan aktivitas siswa setiap pertemuannya.

Proses pembelajaran ini merupakan serangkaian kegiatan guru dan peserta didik atas hubungan timbal balik yang berlangsung dalam situasi edukatif untuk mencapai tujuan tertentu. Peranan guru meliputi banyak hal, yaitu guru dapat berperan sebagai pengajar, pemimpin kelas, pembimbing, pengatur lingkungan belajar, perencana pembelajaran, motivator, dan juga sebagai evaluator (Rusman, 2010).

Berdasarkan proses pembelajaran melalui sintaks dari model ini, hasil belajar peserta didik ranah kognitif siklus I sub materi organ pernapasan dan mekanismenya, peserta didik yang mencapai ketuntasan belajar klasikal adalah sebanyak 19 orang dan peserta didik yang belum tuntas adalah sebanyak 11 orang peserta didik dengan persentase ketuntasan klasikal 63,3\% (belum tuntas). Sedangkan dari hasil belajar peserta didik ranah kognitif siklus II sub materi frekuensi pernapasan dan faktor-faktor yang mempengaruhinya, diperoleh sebanyak 24 peserta didik yang mencapai ketuntasan belajar klasikal, sedangkan 6 orang lainnya belum tuntas dengan persentase ketuntasan di siklus II ini sebesar $80 \%$ (tuntas). Hasil penelitian menunjukkan bahwa model Discovery Learning dapat meningkatkan hasil belajar peserta didik ranah kognitif. Hal ini didukung oleh Sari (2018) bahwa model Discovery Learning dapat meningkatkan aktivitas dan hasil belajar IPA biologi materi sistem ekskresi. Selanjutnya penelitian oleh Widiadnyana, dkk (2014) menyimpulkan bahwa model Discovery Learning dapat meningkatkan hasil belajar IPA dan sikap ilmiah peserta didik. Maladewi (2016) menyimpulkan bahwa model Discovery Learning dapat meningkatkan keterampilan proses peserta didik pada materi ekosistem.

Kemudian hasil penelitian juga menunjukkan peningkatan hasil belajar peserta didik ranah psikomotoris. Adapun rerata skor hasil observasi untuk keseluruhan peserta didik (30 orang) pada siklus I adalah 14,03 dengan 15 orang peserta didik memperoleh nilai baik dan 11 lainnya cukup, namun keseluruhan sudah termasuk dalam kategori baik. Sedangkan rerata skor hasil observasi pada siklus II adalah 17 dengan 30 orang/ seluruh peserta didik memperoleh nilai baik sehingga termasuk dalam kategori baik. Data hasil observasi psikomotorik ini didapatkan peserta didik dalam kelompoknya. Hasil penelitian menunjukkan bahwa model Discovery Learning ini juga dapat meningkatkan hasil belajar peserta didik 
ranah psikomotor. Hal ini didukung oleh Ratnasari dan Erman (2018) bahwa penerapan model Discovery Learning dalam pembelajaran IPA materi zat aditif dapat melatih keterampilan proses sains siswa. Selain itu Maladewi (2016) juga menyimpulkan bahwa model Discovery Learning dapat meningkatkan keterampilan proses peserta didik pada materi ekosistem.

Peningkatan jumlah persentase ketuntasan belajar klasikal peserta didik dan juga hasil belajar peserta didik ranah psikomotorik dari siklus I ke siklus II tersebut menunjukkan bahwa model Discovery Learning dapat meningkatkan hasil belajar peserta didik. Peningkatan hasil belajar ini juga sikarenakan peserta didik lebih aktif selama proses pembelajaran berlangsung. Penerapan model Discovery Learning ini menunjukkan keterlibatan aktif peserta didik dalam proses pembelajaran langsung. Mereka akan menemukan konsep bagi dirinya sendiri, sehingga apa yang didapatkan tidak akan mudah untuk dilupakan. Selaras dengan pernyataan penelitian yang dilakukan oleh Sundari (2018), bahwa model pembelajaran Discovery Learning dapat meningkatkan aktivitas belajar dan hasil belajar peserta didik yang dilihat dari meningkatnya ratarata nilai dari siklus I ke siklus 2 .

\section{PENUTUP}

Simpulan

Berdasarkan penelitian yang dilakukan dapat disimpulkan bahwa pembelajaran dengan menerapkan model Discovery Learning dalam proses pembelajaran pada materi sistem pernapasan manusia di kelas $\mathrm{VIII}_{\mathrm{j}}$ SMPN 5 Kota Bengkulu dapat meningkatkan ketuntasan belajar klasikal peserta didik dari siklus I ke siklus II (ketuntasan kognitif).
Demikian pula dengan ketuntasan psikomotorik yang meningkat dari siklus I ke siklus II.

Saran

Untuk penelitian selanjutnya, diharapkan kepada peneliti agar fokus dalam membimbing peserta didik dan memperhatikan waktu yang diperlukan untuk masing-masing tahapan pembelajaran dengan sebaik-baiknya, agar peserta didik aktif dalam proses pembelajaran langsung dan dapat meningkatkan hasil belajar peserta didik. Sehingga tujuan pembelajaran dapat tercapai secara optimal.

\section{DAFTAR PUSTAKA}

Amalia, N, dkk. Penerapan Model Pembelajaran Discovery Learning untuk Meningkatkan Kemampuan Berpikir Kritis dan Hasil Belajar Kimia. Jurnal Pendidikan Kimia Indonesia, 1 (1): 5

Arikunto, S. 2009. Dasar-Dasar Evaluasi Pendidikan. Jakarta: Bumi Aksara

Hilda, L. 2015. Pendekatan Saintifik pada Proses Pembelajaran. Jurnal Darul 'Ilmi, 3 (1): 76-85

Hosnan. 2014. Pendekatan Saintifik Dan Konstektual Dalam Pembelajaran Abad 21. Bogor: Ghalia Indonesia

Kadir, A. 2015. Menyusun dan Menganalisis Tes Hasil Belajar. Jurnal Al-Ta'dib, 8 (2): 71

Machali, I. 2014. Kebijakan Kurikulum 2013 dalam Menyongsong Indonesia Emas Tahun 2045. Jurnal Pendidikan Islam, III (1): 73

Maladewi, K. 2016. Penerapan Model Discovery Learning pada Materi 
Ekosistem untuk Meningkatkan Keterampilan Proses Siswa Kelas VII $I_{B}$ SMPN 2 Kota Bengkulu. Skripsi tidak diterbitkan. Universitas Bengkulu: Program Studi Pendidikan Biologi FKIP Universitas Bengkulu

Permendikbud Nomor 58 Tahun 2014 tentang Kurikulum 2013 Sekolah Menengah Pertama/ Madrasah Tsanawiyah (salinan)

Putri, Ihdi Shabrona, dkk. 2017. Pengaruh pembelajaran model Discovery Learning terhadap hasil belajar siswa dan aktivitas siswa. Jurnal Pendidikan Fisika, 6 (2): 93

Ratnasari,R.Y dan Erman. 2018. Penerapan Model Discovery Learning dalam Pembelajaran IPA Materi Zat Aditif untuk Melatih Keterampilan Proses Sains Siswa SMP. Jurnal Pensa, 5 (3): 328

Rusman. 2010. Model-model Pembelajaran: Mengembangkan Profesionalisme Guru. Jakarta: PT RajaGrafindo Persada

Salmi. 2019. Penerapan Moedel Pembelajaran Discovery Learning dalam Meningkatkan Hasil Belajar Ekonomi Peserta Didik Kelas XII IPS.2 SMAN 13 Palembang. Jurnal Profit, 6 (1): 15
Sani, R.A. 2014 Pembelajaran Saintifik untuk Implementasi Kurikulum 2013. Jakarta: Bumi Aksara

Sari, F.N. 2018. Peningkatan Aktivitas dan Hasil Belajar melalui Model Discovery Learning dengan Pendekatan Saintifik. Jurnal Diklabio, 2 (2): 86-93

Sudijono, A. 2015. Pengantar Statistik Pendidikan. Jakarta: Rajawali Pers

Sundari, Sri G. 2018. Peningkatan Hasil Belajar Biologi dengan Model Discovery Learning. Jurnal Pendidikan dan Bio Sains 1 (2): 153

Suprihatiningrum, J. 2016. Strategi Pembelajaran: Teori dan Aplikasi. Jogjakarta: Ar-Ruzz Media

Undang-Undang Nomor 20 Tahun 2003 tentang Sistem Pendidikan Nasional

Widiadnyana, I. W., Sadia, I. W. dan Suastra, I. W. 2014. Pengaruh Model Discovery Learning Terhadap Hasil belajar IPA dan Sikap IImiah Siswa SMP. E-journal Program Pascasarjana Universitas Pendidikan Ganesha, 4 (1): 8-11 